\title{
Gandhi and Tagore: A Critical Analysis
}

\section{Inam UI Haq}

Central University of Gujarat, Gandhinagar, Gujarat, India

*Corresponding author: Haq IU, Central University of Gujarat, Gandhinagar, Gujarat, India, Tel: 07567038519; E-mail: mantooinam72@gmail.com

Received date: September 26, 2016; Accepted date: November 03, 2016; Published date: November 09, 2016

Copyright: (c) 2016 Haq IU. This is an open-access article distributed under the terms of the Creative Commons Attribution License, which permits unrestricted use, distribution, and reproduction in any medium, provided the original author and source are credited.

\section{Short Communication}

History is full with the great personalities, who can never be forgotten as they had contributed a lot in their life period. Among them are Gandhi and Tagore, who made a great contribution in world history. Both of them are born in last quarter of the nineteenth century. Tagore in 1861 and Gandhi in 1869 and lived up to the India got independence from the colonial rule [1]. Gandhi and Tagore were so famous that their mutual friend Andrews once argued Tagore as modern, while as Gandhi is the St. Francis of Assisi. While as John Haynes Holmes compared Gandhi and Tagore as Erasmus and Luther (the poet's anxiety). Although both of them were close friends of each other throughout their lives, but there was difference in their intellectual understanding. Besides these differences their friendship remains entirely unbroken.

By reading about Gandhi and Tagore conclusion comes that they argued each other with love and there was no selfishness among them. Their arguments were fully combined with learning, understanding, knowledge, feelings and emotions [2]. By virtue of Andrews Gandhi and Tagore knew each other. When Gandhi was in South Africa fighting for human rights got publicity in India and Tagore respected Gandhi's mission and sent his blessings through Andrews and Pearson and this was the beginning that they began to know each other [1]. When Gandhi left South Africa in 1915 and leaving his phoenix ashram, Tagore provided accommodation to Gandhi and his in mates in santiniketan. This was the first face to face contact between Tagore and Gandhi in 1915 and Gandhi spend six days and some says one month [1,2]. Gandhi tried to imply the experiments which he had done in South Africa like how to run the kitchen and keep the ashram clean and pointing out that special treatment should be provided to Brahmin boys. When Tagore came to know about this statement of Gandhi, he did not tolerate these practices. The other thing that the inmates of Gandhi influenced the Tagore's ashram and students of ashram gave up sugar and ghee and started fasting in order to do well. Tagore did not accept such ideas of Gandhi and called Fasting an evil instead of doing well. "Between 1915 up to 1941 Tagore and Gandhi argued upon personal, national and international issues. Their intellectual difference countered on non-cooperation movement, nationalism and internationalism, the significance of charkha for the attainment of swaraj and on science and faith [2]. Besides these differences there friendship remained unended as it was Tagore whom Gandhi had invited to open annual Gujarati literary conference in 1920 and it was Gandhi who gave the Tagore the title of Gurudev. Meanwhile Tagore has given the name Mahatma to Gandhi when he came back to India 1915. However both Gandhi and Tagore had same aspirations for the freedom of India, but they could not understand the principles of non-cooperation for achieving complete independence. Tagore supported Gandhi whole heartily during the Rowlatt Acts. However Tagore had some differences on Hindi-Urdu as a national language. His view was that it creates problem for the people living in south. In this connection Gandhi said that Kabir, Nanak, Shivaji greater than Raja Ram Mohan Roy and Tilak. Tagore was not pleased and strongly protested saying Gandhi is admired in his own principles, which is dangerous form of egotism that even greater people suffer at times [1]. However when the tragedy of the Jallianwala bagh massacre happen, Tagore followed whole heartily and first he used the word "Mahatmaji" for Gandhi when he was arrested on 08 April 1919. In an open letter Tagore wrote to Gandhi that you can lead the country to the path of conquest [1]. Tagore was disappointed with the actions of General Dyer and opposed openly and supported Gandhi. After that Gandhi launched non-cooperation movement in 1920. Tagore was outside India, after returned back he feel himself disturbed in such environment and soon he attacked the non-cooperation movement of Gandhi in his famous speech at Calcutta university institute called Satyagraham or the call of truth. Tagore openly criticizes the noncooperation calling it as political asceticism. He argued that instead of non-cooperation, India should stand on cooperation of all people of the world. Tagore further wrote that non-cooperation hurts the truth. Love is the ultimate truth of soul in meeting the east and west [2]. The other difference between them was like nationalistic and Internationalistic, Gandhi was a nationalistic and Tagore argues that nationalistic is always selfish and leads to moral pervasion. The burning of foreign clothes is selfish nationalism. While Gandhi argues that anyone who is not nationalist does not become an internationalist. Not only Tagore, their mutual friend C.F Andrews also criticized Gandhi on behalf of word foreign. They both thought that it created hate chaos among the people.

Gandhi respected the criticism of Tagore and gave answer to the poet in an essay called the poets anxiety. In this essay Gandhi praised the works of Tagore and said that the poet of Asia has rendered his service to India by his poetic interpretation. Gandhi argues that the poet is anxious that India must take false steps and poet should not fear that it is a step of separation, exclusiveness, narrowness. It is only a doctrine of negation and despair. "He thinks that non-cooperation is like Chinese wall between India and west. Non-cooperation is based on voluntary and mutual respect and trust. Non-cooperation is a protest against an unwitting and unwilling participation in evils" [3]. The poet was anxious that the students leave schools and joined in the non-cooperation that is not good for the development of India. Tagore firmly criticized Gandhi that the students should not be called upon to leave the governments schools. Gandhi answered him that I am sure that the government schools unmannered us, rendered us. They filled our hearts with discontent and intended to become clerks and interpreters and take their own benefits. They are keeping us as slaves. Gandhi argues that it becomes sinful to send our children to government schools [4]. For Gandhi non-cooperation is a kind of invitation to government to cooperate with their own terms and it is right of every nation and it is duty of every government [2]. The debate of Gandhi and Tagore were published in two newspapers like modern review and young India. Reading the arguments behind non- 
cooperation movement given by Gandhi in the poet's anxiety. Tagore issued an essay in October 1921, namely the call of truth. Tagore argues that that all human beings were parasites of the environment. Their progress and growth is dedicated with nature. Tagore argues that man enjoys his inner freedom, for him nothing is impossible. First a man should not attain Swaraj at his inner environment then they would be deprived of the Swaraj from the outside world also. Tagore argued that the inner freedom is more precious than the prayers and petitions that create constant burden. Tagore warned in this essay that Gandhi's main motive is to hate the foreigners and not love of country [5].

Non-cooperation took many forms like civil disobedience, fasting, swadeshi, burning of foreign clothes and use clothes produced in the country and propagation of spinning wheel, strikes, Hartals and nonpayment of taxes. Tagore did not like these ideas of Gandhi and he termed these as narrowness [1]. In the call of truth, Tagore argues that these things create hatred towards foreigners and Tagore was fully supported by Andrews on the matter of burning of foreign clothes. Tagore argues that "power in all forms is irrational" [6]. It is like a horse cart that drags the people blindly. Tagore remained critical towards burning of foreign clothes and spinning wheel. He argued that it leads us towards destruction and closed the doors of economic advances. He further argued that "Swaraj is not a matter of mere selfsufficiency in the production of clothes. Its real place is with us, the mind with its diverse power goes on building Swaraj for itself" [6]. Tagore firmly said that that I don't obey to burn foreign clothes as I strictly put fight against bad habit of obeying blindly orders and secondly the clothes burnt were not mine, but they belonged to those who sorely need them. My eyes did not see the nakedness, which had already kept our women as prisoners in their homes [5]. Tagore criticizes both non-cooperation and khadi movements as there is to create despotism, chaos and hatred among the country and lead bad effect on economy. Thus the call of truth ends with the limitations of narrow nationalism and sees the vast dimensions of India in world context. So call of truth of Tagore was to know the answer of urgent call of universal humanity [6]. The Tagore-Gandhi controversy is based on two aspects of the meaning of Swaraj in its fullest sense. Tagore argued that India choose a leader who did not lead the country towards the development but towards destruction, as India followed him blindly without not knowing the result of that. Tagore argues that Gandhi's teachings had implications at international level and restricted the freedom of India without the knowledge and advances of western world [6].

Gandhi replied back on 13th October 1921 in young India. His article "the great sentinel". Gandhi appreciated the poet that had criticized the charka, boldly declare revolt against it and there is blind obedience on scale of his leadership.it is a true fact that the educated did not understand the truth underlying spinning and weaving [1]. As Tagore's essay warns all those whose impatience are betrayed into intolerance and Gandhi called the poet as a sentinel warning us against the enemies' bigotry, intolerance and ignorance. Gandhi in his essay tried to answer the arguments which Tagore had highlighted in the call of truth charkha and why charkha was considered important. Gandhi believed that the spinning wheel as the giver of plenty. Gandhi tried to prove the truth which was underlying beneath the spinning wheel. Gandhi argues India as a house on fire, as man hood is being daily scorched. People are dying with hunger, as there is no work to buy food. Gandhi's vision was that only cities were not India. India has seven hundred and fifty thousand villages. Gandhi believed that India is growing poorer and poorer and if we don't look towards it, India will collapse together [7]. Gandhi called Tagore as undisputed master of the world as he lived in the world of his own creations, own ideas and me as a slave of somebody else creation the spinning wheel. The poet is an inventor and he creates, destroys and recreates and me as an explorer discover a thing and cling to it. Gandhi argued that poet is thinking that charka as the death of the nation. The truth is that charka is essential to live an honorable life like prince. There should be no difference between a prince and a peasant [5]. For Gandhi spinning wheel was the recognition of dignity of labour. Tagore criticizes Gandhi's charkha not only in the call of truth, but in another essay the cult of charkha and raised question that why Gandhi narrowly say spin and weave, spin and weave and why not bringing all forces of land into action [2]. Gandhi considered it as a sin to wear foreign clothes or to eat American wheat and let my neighbor grain dealer starve for customers. To wash my sins I consider that foreign clothes should go into flames and it is better to wrap my naked body with the cloth that my neighbor spins at home. In my country it is insult to naked by giving them cloth instead of work which they sorely need. It is act to commit sins by giving them cloth, which I cannot do [7].

Another difference that arose between Gandhi and Tagore when Bihar was rocked by a serve earth quake on 15th January 1934. Gandhi this time was working on the untouchables and considered the earthquake as a divine punishment sent by God and we are doing sins and related untouchability with the Bihar earth quake saying that there is some connection between them. When Tagore read this statement he got angry and condemned the statement strongly. As Gandhi considered modern science as destruction for humanity. Not only Tagore, Nehru and Andrews also criticize Gandhi for relating everything with God and don't look behind the scientific reason $[1,8]$.

\section{Conclusion}

By summarizing the whole debate between Gandhi and Tagore, we came to the conclusion that both Gandhi and Tagore were close friends and intellectually opponent in nature. Louis Fischer argued that both Gandhi and Tagore were opposite in nature. "Gandhi as wheat field and Tagore as the rose garden". Both Gandhi and Tagore were great personalities who sacrificed their every portion of life for the welfare of their country. They respected each other a lot and were friendly related. However there were differences in their ideas, thoughts. Their arguments were not based on learning, knowledge, understanding and emotions. Both gave names to each other like Tagore gave the name Mahatma to Gandhi and Gandhi gave him the title Gurudev. Both of them met in March 1915, when Gandhi came to shantiniketan and their intermediator Andrews played a great role in between them. The poet was an imaginative thinker, while as Gandhi was a reflective thinker. Both were the worshippers of Satyam, Shivam and Sundram. The poet was known for his universality and his love for humanity. This came to know through his songs which he played during swadeshi movement in Bengal and Gandhi got inspired with these songs.

Tagore fully supported Gandhi against the Rowlatt act and he uses Mahatmaji in his letters and was hopeful that Gandhi can lead us towards the path of conquest. However with the adoption of noncooperation movement which comes out in different shapes like civil disobedience, burning of foreign clothes, strikes, hartals, fastings, charkha and non-payment of taxes. Tagore did not like the ideas and thinking of Gandhi and termed his non-cooperation a political asceticism and burning of foreign clothes as selfish nationalism. Tagore believes that Gandhi's egoism can lead India towards destruction and Gandhi is leading the people blindly. In short we can say that their 
differences in ideas were based on non-cooperation, burning of foreign clothes, charkha, fasting, Hindi-Urdu as a national language. Both arguments in the essays or letters namely the poet's anxiety, the call of truth, the great sentinel and the cult of charkha. According to Jawaharlal Nehru, both Gandhi and Gurudev were one hundred percent India's children, the inheritors, representatives and expositors of her age culture. The surprising thing is that both of these men should differ from each other so greatly. No two persons could probably differ as much as Gandhi and Tagore.

\section{References}

1. Harold C (2003) Indian critiques of Gandhi. State University of New York Press 33: 243-245.
2. Bindu P (2001) Mahatma Gandhi and his temporaries. Indian Institute of Advanced Study, Shimla.

3. Sabyasachi B (1997) The mahatma and the poet. National Book Trust of India.

4. Humer AJ (1994) The Gandhi reader. Grove Press, New York.

5. Narayan D (2009) My life my message. Oriental black swan private limited.

6. Denis D (1993) Mahtma Gandhi non-violent power in action. Columbia University Press, New York.

7. Charles AF (2005) Mahatma Gandhi his life and ideas. Jaico Publishing House.

8. Shriman N (1968) The selected works of Mahatma Gandhi. Navajivan Publishing House. 